\title{
THE BIOGEOGRAPHY OF SHALLOW-WATER MACROFAUNA AT HEARD ISLAND
}

\author{
by Graham J. Edgar and Harry R. Burton
}

(with two tables)

\begin{abstract}
EdGar, G.J. \& BURTON, H.R., 2000 (30:vi): The biogeography of shallow-water macrofauna at Heard Island. In Banks, M.R. \& Br •wn, M.J. (Eds): HEARD ISLAND PAPERS. Pap. Proc. R. Soc. Tasm. 133(2): 23-26. https://doi.org/10.26749/rstpp.133.2.23 ISSN 0080-4703. School ofZoology, University of Tasmania, GPO Box 252-05, Hobart, Tasmania, Australia 7001 (GJE); Australian Antarctic Division, Channel Hwy, Kingston, Tasmania, Australia 7050 (HRB).
\end{abstract}

Collections of 23 macroinvertebrate taxa associated with Durvillaea antarctica holdfasts and 58 invertebrate taxa associated with artificial substrata collectors are described from shallow-water and intertidal habitats at Heard Island. The fauna sampled possessed strong biogeographic affinities with the Kerguelen Island fauna and, to a slightly lesser extent, the fauna recorded at Macquarie Island but negligible affinity with the Antarctic. Experiments involving the offshore tethering of $D$. antarctica holdfasts indicated that epifaunal invertebrates rapidly abandoned detached holdfasts, but that the few species surviving after one day could probably survive long periods adrift.

Key Words: shallow-water macrofauna, invertebrate taxa, Durvillaea antarctica, Subantarctic fauna, Heard Island.

\section{INTRODUCTION}

Heard Island, Kerguelen Island and MacquarieIsland occupy pivotal geographic positions in the Southern Hemisphere with respect to the testing of biogeographical hypotheses. While Heard Island and Kerguelen Island are connected geographically by the relatively shallow Kerguelen-Gaussberg Ridge ( $<400 \mathrm{~m}$ depth; Houtz et al. 1977), these islands are separated by a steep water-temperature gradient $\left(\approx 4^{\circ} \mathrm{C}\right)$ due to the intermediate location of the Antarctic Convergence. Kerguelen Island has a similar oceanographic climate to Macquarie Island but is geographically separated by long distance and deep water. Consequently, a knowledge of the affinities of Heard Island, Kerguelen Island and Macquarie Island marine biotas should allow the relative influences of water temperature (and its correlates) and the dispersal abilities of Subantarctic species to be assessed. In contrast to the shallow-water faunas of Kerguelen Island (Arnaud 1974) and Macquarie Island (Simpson 1976, Lowry et al. 1978, Edgar 1987, O'Hara 1998), which have been relatively well studied, very little has been reported on the Heard Island macrobenthos (Simpson 1988). Shallow inshore species have only been collected in the area at a single BANZARE station in 1929 and as a result of ad hoc collections by ANARE expeditioners (Dell 1964), while Smith \& Simpson (1985) provided a brief description of intertidal zonation patterns.

The presence of any species at Heard Island will be the result of either vicariant or dispersal processes (Edgar 1986, O'Hara 1998). Thus, species either have a long past association with Heard Island and its associated landmass or have arrived comparatively recently by benthic or pelagic migration. Knowledge of the relative importance of these processes has applied as well as theoretical importance. Information on the timescale of colonisation rates is crucial if, for example, the rate of recovery of the island's biota following a catastrophic disturbance, such as an oilspill, is to be predicted.

The wide distribution of many benthic species around the Subantarctic region has led many biogeographers to consider that dispersal, in particular the dispersal of benthic species associated with drifting seaweeds, is more important than vicariance in explaining species distributions for shallow-water Subantarctic taxa (Knox \& Lowry 1977). Detached plants of the giant kelp Macrocystis pyrifera are widely considered the main vector contributing to this process (Beurois 1975, Edgar 1987). Macrocystis pyrifera does not occur at Heard Island, hence the hypothesis that $M$. pyrifera greatly enhances dispersal rates can be tested, using the prediction that the lack of $M$. pyrifera at Heard Island has inhibited the colonisation of epipelagic immigrants, and that the island is faunally depauperate as a consequence.

Alternatively, a second large macro-algae that drifts long distances, Durvillaea antarctica, may be responsible for transporting much of the benthic fauna to Heard Island, and from Heard Island further eastwards. Drifting $D$. antarctica plants are approximately 20 times more abundant than $M$. pyrifera plants in the open sea, with one estimate of 70 million kelp rafts drifting in the Southern Ocean (Smith 1998). In order to test the hypothesis that $D$. antarctica provides a major dispersal vector, Durvillaea holdfasts were detached from the shore and tethered offshore at Heard Island, with survival of associated invertebrates assessed after three months adrift. If $D$. antarctica provides an important dispersal mechanism, then numerous species are predicted to survive in association with detached plants.

\section{METHODS}

Mobile macrofaunal species were collected by attaching artificial algal habitats $(\approx 70$ g clumps of tanikalon rope fibre) to individual bricks, placing the bricks into the field at Heard Island and retrieving them with associated animals after three months submergence. Invertebrates $>0.5 \mathrm{~mm}$ sieve-size were extracted from artificial algal habitats by sieving the preserved samples using the methods described in Edgar (1993). Four artificial habitats were placed in lower intertidal rock pools at Atlas Cove on 27 November 1987, and six artificial habitats at $8-9 \mathrm{~m}$ depth in Corinthian Bay on 21 November 1987.

Survival of benthic animals when associated with drifting $D$. antarctica plants was assessed by prising plants from rocks in the lower intertidal zone at Atlas Cove, attaching the plants to ropes, and then slowly towing the plants 
$\approx 500 \mathrm{~m}$ offshore. A preliminary trial indicated that whole plants attached to lines created too much drag for anchors, hence holdfasts were separated from fronds and tethered at the sea surface to anchored buoys. This process was undertaken on 20 November 1987 , with four of the tethered holdfasts collected for faunal analysis the next day. Two holdfasts were lost to wave action during the study, with the remaining two holdfasts collected after 93 days afloat. Hold fasts ( 4 replicates) were also collected as faunal controls from the shore at the start (20 November 1987) and end of the experiment (21 February 1988).

In order to assess whether recruitment was occurring on tethered holdfasts, four replicate holdfasts were defaunated by submersion in freshwater for ten minutes at the start of the experiment before offshore tethering (Edgar 1992). Two of these recruitment control holdfasts were lost through wave action and two collected at the end of the experiment.

On collection, all holdfasts were carefully placed into plastic bags and formalin added. Animals were later separated from holdfasts in the laboratory by pouring the washed contents of the bags through a $0.5 \mathrm{~mm}$ sicve after the holdfast had been broken apart; animals retained by the sieve were counted under a binocular microscope using the same methods as for artificial algal habitats.

\section{RESULTS}

A total of 58 macrofaunal species was collected from artificial algal habitats during the study (table 1), and a total of 23 species was collected from Durvillaea holdfasts, including ten species not collected from artificial habitats (table 2). The great majority of Heard Island taxa identified to species have been recorded previously from Kerguelen Island, with many species also recorded from Macquarie Island. In contrast to this Subantarctic affinity, no species were collected that possessed a Heard Island/Antarctic distribution.

The level of endemicity of the Heard Island benthos does not appear high. Amongst the five animal groups fully identified by taxonomists (Amphipoda, Isopoda, Tanaidacea, Mollusca and Echinodermata), only the gastropod Laevilittorina heardensis and the isopod Limnoria carptora are presently regarded as endemic. A further 12 species $(31 \%)$ could not be assigned to known taxa. Most of these species probably occur in other Subantarctic locations but were not fully identified because specimens were immature or the wrong sex for adequate species determination.

Few animals survived in association with tethered Durvillaea holdfasts, even for 24 hours adrift (table 2). After the rapid initial population decline, four species (Hyale hirtipalma, Limnoria carptora, Laevilittorina heardensis and Oligochaeta sp. 1) persisted in low numbers on holdfasts until the conclusion of the experiment. Three of these species were collected from defaunated holdfasts tethered as settlement controls, hence recruitment as well as in situ survival probably contributed substantially to numbers collected on tethered plants, although some animals inhabiting deep cavities may have survived the freshwater defaunation process. The amphipod Paramoera austrina f. kergueleni greatly increased numbers on tethered holdfasts, presumably as a result of recruitment, while a second amphipod, Probolisca ovata, was collected solely on defaunated plants.

\section{DISCUSSION}

The small collections described here indicate that macrofaunal species richness at Heard Island is moderate rather than depauperate, with 42 macrofaunal species collected from four artificial habitats at Atlas Cove and 38 species amongst six habitats at Corinthian Bay. By comparison, the number of species associated with four artificial habitats of similar construction in other regions were 32 in a Laminaria kelp forest at Millport, Scotland (G. Edgar, pers. obs.) and 39 in Langebaan Lagoon, southwestern Africa (G. Edgar, pers. obs.), and ranged from a mean of 20 in the Bathurst Harbour estuary to 70 in Port Davey embayment, southwestern Tasmania (Edgar 1991). The absence of Macrocystis pyrifera at Heard Island does not appear to have substantially depressed the diversity of the shallow-water fauna.

Although Heard Island is located south of the Antarctic Convergence, the associated shallow-water macrobenthos has clear Subantarctic rather than Antarctic affinities. Geographic position clearly has a much greater biogeographic influence on the local marine fauna than contemporary climatic conditions. The slightly stronger affinities of the Heard Island benthos with Kerguelen Island (17 taxa) than Macquarie Island (13 taxa) also indicate that geographic connections have a predominant role in influencing the composition of the Heard Island benthos. Moreover, the much stronger biotic relationships with Macquarie Island than with the geographically closer Antarctic continent indicate that dispersal processes mediated by the West Wind Drift have greatly influenced the composition of Heard Island benthos.

A large proportion of the species present at both Heard and Macquarie Islands (e.g. Hyale hirtipalma, Anasterias mausoni and Paramoera austrina) lack pelagic larval stages, hence transportation by epipelagic drift probably has contributed to the dispersal of these taxa. Such species may have dispersed in association with drifting $D$. antarctica holdfasts; however, the majority of taxa were probably not transported in this way. Although the experiments described here were extremely limited in terms of replication and controls, and should therefore be regarded as preliminary, initial survival of taxa in association with detached $D$. antarctica holdfasts was very poor. The majority of individuals and species emigrated from $D$. antarctica holdfasts within one day, whereas most species present on tethered $M$. pyrifera holdfasts survived for $>191$ days at sea in experiments off Tasmania (Edgar 1987). Thus, despite the great abundance of Durvillaea rafts in the Southern Ocean (Smith 1998), D. antarctica probably provides a relatively poor vehicle for dispersal in comparison with $M$. pyrifera. Long-term survival of Laevilittorina heardensis on tethered holdfasts nevertheless indicates that $D$. antarctica may play an important role in the dispersal of a few intertidal invertebrate taxa. Species surviving for even one day at sea are probably capable of surviving long periods adrift. We note, however, that $L$. heardensis has not travelled long distances from Heard Island, as it is an endemic species, with the congener L. caliginosa abundant at Macquarie Island.

Additional support for the hypothesis that species disperse more often in association with $M$. pyrifera than with $D$. antarctica is provided by published descriptions of holdfast faunas at Heard Island (table 2), Kerguelen Island (Arnaud 1974) and Macquarie Island (Smith \& Simpson 1995, 1998). Only three species, Probolisca ovata, Omalogyra 
TABLE 1

Mean abundances of invertebrates collected from artificial algal clumps placed in Atlas Cove and Corinthian Bay

\begin{tabular}{|c|c|c|c|c|c|c|c|}
\hline \multirow[t]{3}{*}{ Taxon* } & \multirow[t]{3}{*}{ Distribution ${ }^{\dagger}$} & \multicolumn{2}{|c|}{ Locality } & \multirow[t]{3}{*}{ Taxon* } & \multirow[t]{3}{*}{ Distribution $^{\dagger}$} & \multicolumn{2}{|c|}{ Locality } \\
\hline & & Arlas & orinthian & & & Atlas & Corinthian \\
\hline & & Cove $e^{\frac{\hat{f}}{4}}$ & Bay $\$$ & & & Cove & Bays \\
\hline Amphipoda & & & & Mollusca (cont.) & & & \\
\hline Cerapus oppositus K.H. Barnard & & 4.3 & 2.0 & Onobasp. & & 1.5 & 0.5 \\
\hline Gitanopsis squamosa (Thomson) & $\mathrm{K}, \mathrm{M}$ & 5.8 & & Zalipais sp. & & 6.0 & \\
\hline Hyale hirtipalma (Dana) & $\mathrm{K}, \mathrm{M}$ & 0.5 & 1.5 & Lissarca rubrofusca Smith & $\mathrm{K}$ & & 153.2 \\
\hline Oradarea tridentata K.H. Barnard & $\mathrm{K}$ & 23.5 & & ?Hemiarthrum setulosum Dall & $\mathrm{K}, \mathrm{M}$ & 0.3 & \\
\hline Paramoera austrina F. kergueleni & $\mathrm{K}$ & 102.0 & 19.7 & Brachiopoda & & & \\
\hline Bellan Santini \& Ledoyer & & & & Indet. sp. & & 0.3 & \\
\hline Probolisca ovata Stebbing & $\mathrm{K}, \mathrm{M}$ & 256.5 & 3.0 & Arthropoda & & & \\
\hline Schraderia gracilis Pfeffer & $\mathrm{K}, \mathrm{M}$ & 1.0 & 0.5 & Acarina sp. 1 & & 3.7 & 18.7 \\
\hline Gammaropsis sp. & & 3.3 & & Acarina sp. 2 & & 0.3 & 0.3 \\
\hline Ischyrocerus sp. & & 23.5 & 0.2 & Pycnogonida sp. 1 & & 0.5 & \\
\hline $\begin{array}{l}\text { Jassa sp. } \\
\text { Metotoides so }\end{array}$ & & $\begin{array}{r}14.5 \\
0.3\end{array}$ & 0.8 & Pycnogonida sp. 2 & & & 0.2 \\
\hline $\begin{array}{l}\text { Metopoides sp. } \\
\text { Paramoera sp. }\end{array}$ & & $\begin{array}{r}0.3 \\
198\end{array}$ & 1.4 & Pycnogonida sp. 3 & & & 0.5 \\
\hline $\begin{array}{l}\text { Paramoera sp. } \\
\text { Podoceris sp. }\end{array}$ & & 15.0 & 1.0 & Echinodermata & & & \\
\hline Isopoda & & & & Anasterias mawsoni (Koehler) & M & 0.8 & \\
\hline Caecianiropsis ectiformis (Vanhoffen) & $\mathrm{K}$ & 47.5 & 0.2 & Cnidaria & & & \\
\hline Califanthura pinquoin (Kensley) & & 0.8 & 0.5 & Actiniaria sp. & & 0.3 & \\
\hline Cassidinopsis emarginata & $\mathrm{K}, \mathrm{M}$ & 0.5 & 1.0 & Platyhelminthes & & & \\
\hline (Guérin-Menéville) & & & & Polycladida sp. 1 & & 1.0 & \\
\hline Euvalentinia darwini (Cunningham) & $\mathrm{K}$ & & 0.8 & Polycladida sp. 2 & & 0.3 & \\
\hline Santia marmorata (Vanhoffen) & $\mathrm{K}$ & 3.5 & 0.2 & Nemertini & & & \\
\hline Uromunna dentata (Vanhoffen) & $\mathrm{K}$ & 2.0 & 0.2 & Indet. sp. 1 & & 65.3 & 14.7 \\
\hline Munnasp. & & 0.5 & & Indet. sp. 2 & & & 0.3 \\
\hline & & & & Annelida & & & \\
\hline $\begin{array}{l}\text { Apseudes antarticus Beddard } \\
\text { Nototanais dimorphus (Beddard) }\end{array}$ & $\begin{array}{l}M \\
K M\end{array}$ & 03 & 0.2 & ?Eunoesp. & & 0.8 & \\
\hline Zeuxo phytalensis Sieg & $\mathrm{M}, \mathrm{M}$ & 0.3 & 02 & Polydorella sp. & & & 0.7 \\
\hline Zeuxoides pseudolitoralis Sieg & M & 08 & 0.2 & ?Proclea sp. & & 0.5 & \\
\hline & & 0.0 & 2.2 & Schistomeringos sp. & & & 12.3 \\
\hline Mollusca & & & & Exogoninid sp. & & & 0.5 \\
\hline Eatoniella caliginosa (Smith) & $\mathrm{K}$ & 1005.8 & 14.3 & Phyllodocid sp. & & & 0.2 \\
\hline Laevilittorina heardensis Dell & & 9.8 & 1.8 & Polynoid sp. & & & 0.2 \\
\hline Macquariella hamiltoni (Smith) & M & 24.0 & 0.5 & Oligochaeta sp. 1 & & & 9.2 \\
\hline Nacella maquariensis (Finlay) & M & 0.3 & & Hirudinea sp. & & 0.5 & 0.2 \\
\hline Omalogyra cf, atomus (Phillipi) & & 5.0 & 6.6 & & & & \\
\hline Skenella cf. sinapi (Watson) & & I.8 & & & & & \\
\hline Laevilittorina sp. & & & 0.2 & & & & \\
\hline
\end{tabular}

* In addition to described species listed here, Limnoria carptora Cookson, an isopod endemic to Heard Island, and Nacella kerguelensis (Smith) and Pellilitorina setosa (Smith), two gastropods also recorded from Kerguelen Island, were collected from Durvillaea antarctica holdfasts.

Indicates whether the species is also recorded from Kerguelen Island (K) or Macquarie Island (M).

‡ Four clumps in lower intertidal zone.

six clumps.

atomus and Nacella kerguelensis, have been recorded from $D$. antarctica holdfasts at both Heard and Kerguelen Islands, only Hyale hirtipalma from $D$. antarctica holdfasts at both Heard and Macquarie Islands, and only Parawaldeckia kidderi from $D$. antarctica holdfasts at both Kerguelen and Macquarie Islands. By comparison, nine invertebrate species have been recorded in $M$. pyrifera holdfasts at both Kerguelen and Macquarie Islands (Arnaud 1974, Edgar 1987).

The lack of similarity between $D$. antarctica holdfast faunas recorded at the different Subantarctic islands may nevertheless be attributable to small collections having been made at each island and the paucity of data on intraisland variation between sites. The only information on holdfast faunas at sites separated by distances exceeding several kilometres is provided for two sites at Macquarie Island (Smith \& Simpson 1998), with the majority of abundant species present at the two sites. Additional collections from multiple sites around each island and collections of drifting plants are required to clarify unequivocally the biogeographic importance of Durvillaea and Macrocystis drift.

\section{ACKNOWLEDGEMENTS}

The study would not have been possible without the field assistance of E. Woehler and the army LARC detachment, and taxonomic determinations by J.K. Lowry (Amphipoda), F. Rowe (Echinodermata), G.C.B. Poore (Isopoda), W. Ponder (Mollusca), P. Hutchings (Polychaeta) and J. Sieg (Tanaidacea). Comments on the draft manuscript by $S$. Smith and T. O'Hara were much appreciated. 
TABLE 2

Abundance of invertebrate species collected from attached Durvillaea antarctica holdfasts at the beginning and conclusion of experiment

\begin{tabular}{|c|c|c|c|c|c|c|c|c|c|c|c|c|c|c|c|c|}
\hline \multirow[b]{3}{*}{ Hyale hirtipalma } & \multicolumn{8}{|c|}{ Shore* } & \multicolumn{8}{|c|}{ Tethered } \\
\hline & \multicolumn{4}{|c|}{20 Nov 1987} & \multicolumn{4}{|c|}{21 Feb 1988} & \multicolumn{4}{|c|}{1 day } & \multicolumn{2}{|c|}{93 day } & \multicolumn{2}{|c|}{$\begin{array}{l}93 \text { day } \\
\text { control }\end{array}$} \\
\hline & 3 & 10 & 1 & 1 & 92 & 34 & & & & & 1 & 1 & & 1 & 12 & \\
\hline Paramoera austrina f. kergueleni & 1 & 1 & 2 & & & & & & & & & & 38 & 34 & 55 & 23 \\
\hline Jassa sp. & & 1 & & & & & & & & & 2 & & & & & \\
\hline Probolisca ovata & & & & & & & & & & & & & & & 1 & \\
\hline Limnoria carptora & 4 & 97 & 36 & 56 & 492 & 11 & 6 & 79 & 4 & 1 & 1 & & 3 & 3 & & 2 \\
\hline Cassidinopsis emarginata & & 1 & & & & & & & & & & & & & & \\
\hline Zeuxoides pseudolitoralis & & & & & 5 & & & 1 & & & & & & & & \\
\hline Collembola sp. & 1 & & & & 18 & & 1 & 1 & & & & & & & & \\
\hline Coleoptera sp. & 1 & & & 1 & & & & & & & & & & & & \\
\hline Acarina sp.3 & 6 & 1 & & & 34 & 2 & 3 & 10 & & & & & & & & \\
\hline Laevilittorina beardensis & & 59 & 12 & & 325 & 38 & 2 & 55 & 3 & 1 & 2 & 1 & 1 & 2 & & \\
\hline Zalipais sp. & & 2 & & & & & & & & & & & & & & \\
\hline Omalogyra cf. atomus & 1 & & & & & & & & & & & & & & & \\
\hline Eatoniella caliginosa & & 14 & & & & & & & & & & & & & & \\
\hline Nacella kerguelensis & & & & & 3 & & & & & & & & & & & \\
\hline Pellilitorina setosa & & & & & 5 & & & & & & & & & & & \\
\hline Capitella sp. & & 5 & 1 & & & & & & & & & & & & & \\
\hline Jasmineira sp. & & 35 & 5 & 2 & & & & & & & & & & & & \\
\hline ?Proclea sp. & & 1 & & & & & 1 & 1 & & 1 & & & & & & \\
\hline Oligochaeta sp. 2 & 1 & & & & & & & & & & & & & & & \\
\hline Oligochaeta sp. 1 & 4 & 21 & 16 & 8 & 63 & 16 & 4 & 63 & & & & & & 2 & 5 & \\
\hline Polycladida sp. 3 & & 2 & & & 37 & & 1 & 1 & & & & & & & & \\
\hline Polycladida sp. 4 & 1 & & & & & & & & & & & & & & & \\
\hline
\end{tabular}

* Four replicates collected as faunal control on each occasion. * i.e. buoyed at sea for one and 93 days. $\quad$ Two lost to wave action.

s Four defaunated by submergence in freshwater at the commencement of the study; two lost to wave action.

\section{REFERENCES}

Arnaud, P.M., 1974: Contribution a la bionome marine benthique des régions antarctiques et subantarctiques. Téthys 6: 456-656.

Beurois, J., 1975: Etude écologique et halieutique des fonds de pêche et des espèces d'interêt commerciel (langoustes et poissons) des îles Saint-Paul et Amsterdam (Océan Indien). Com. Nat. Fr. Rech. Antarct. 37: 1-91.

DeLL, R.K., 1964: Marine Mollusca from Macquarie and Heard Islands. Rec. Dom. Mus. NZ 4: 267-301.

EDGAR, G.J., 1986: Biogeographical processes in the Southern Hemisphere marine environment. In Westermeier, R. (Ed.): ACTAS II CONGRESO NACIONAL SOBRE ALGAS MARINAS CHILENAS. Universidad Austral de Chile, Valdivia, Chile: 29-46.

EDGAR, G.J., 1987: Dispersal of fauna and floral propagules associated with drifting Macrocystis pyrifera plants. Mar. Biol. 95: 599-610.

EDGAR, G.J., 1991: Distribution patterns of mobile epifauna associated with rope fibre habitats within the Bathurst Harbour estuary, south-western Tasmania. Estuar. Coast. Shelf Sci. 33: 589-604.

EDGAR, G.J., 1992: Patterns of colonization of mobile epifauna in a Western Australian seagrass bed. J. Exp. Mar. Biol. Ecol. 157: 225-246.

EDGAR, G.J., 1993: Measurement of the carrying capacity of benthic habitats using a metabolic-rate based index. Oecologia 95: 115-121.

Houtz, R.E., HAYFs, D.E. \& MARKL, R.G., 1977: Kerguelen Plateau bathymetry, sediment distribution and crustal structure. Mar. Geol. 25: 95-130.
KNOX, G.A. \& LOWRY, J.K., 1977: A comparison between the benthos of the Southern Ocean and North Polar Ocean, with special reference to the Amphipoda and Polychaeta. In Dunbar, M.J. (Ed.): POLAR OCEANS. Arctic Institute of North America, Calgary, Canada: 423-462.

Lowry, J.K., Horning, D.S., Poore, G.C.B. \& Ricker, R.W., 1978: THE AUSTRALIAN MUSEUM MACQUARIE ISLAND EXPEDITION, SUMMER 1977-1978. Australian Museum Trust, Sydney.

O'HARA, T., 1998: Origin of Macquarie Island echinoderms. Polar Biol. 20: 143-151.

SimpSON, R.D., 1976: The shore environment of Macquarie Island. ANARE Rep., Ser. B(I) 125: 1-41.

SIMPSON, R.D., 1988: Developments in the studies of subantarctic shores, with particular reference to Macquarie Island. Pap. Proc. R. Soc. Tasm. 122: 211-217.

SMrTH, S.D.A., 1998: The potential for dispersal of marine invertebrates by rafts of Durvillaea antarctica. ANARE Res. Notes 101: 37.

SMiTh, J.M.B. \& Simpson, R.D., 1985: Biotic zonation on rocky shores of Heard Island. Polar Biol. 4: 89-94.

SMith, S.D.A. \& Simpson, R.D., 1995: Effects of the Nella Dan oil spill on the fauna of Durvillaea antarctica holdfasts. Mar. Ecol. Prog. Ser. 121: 73-89.

SMITH, S.D.A. \& SIMPSON, R.D., 1998: Recovery of benthic communities at Macquarie Island (sub-Antarctic) following a small oil spill. Mar. Biol. 131: 567-581.

(accepted 25 January 1999) 